\title{
Students' Syntax Error in Making English Conversation: An Error Analysis Study
}

\author{
Ida Bagus Gde Nova Winarta, I Wayan Eka Dian Rahmanu \\ Universitas Mahasaraswati Denpasar, Politeknik Negeri Bali \\ idabagusnova@unmas.ac.id, rahmanu.eka@pnb.ac.id
}

\begin{abstract}
This Research entitled "Students' Syntax Error in Making English Conversation, An Error Analysis Study. Basically, it is commonly found that English structure was difficult learned by Indonesian native elementary students. This study was focused on the exploration of foreign language errors and mistakes uttered by younger students. The research method applied in this research consists of approach research, kind and data source, method, and technique of collecting data, method, and technique of analyzing data, and method and technique of presenting the data analysis. A qualitative approach was used in this research and the data source was done by the researcher toward Elementary School 5th Grade Students. The method used in collecting data was by using the observation method and interview method. Then, the result of the analysis was presented by using formal and informal methods. The discussion of the problems was preceded by errors in syntax, such as errors in the scope of clause and phrase, the omission of article and preposition, the omission of the copula be, and error in using to (infinitive). From the result and discussion, it could be concluded that the researcher found some errors in using English done by the Elementary School 5th Grade Students, related to syntax. The writer was aware that this research has some limitations or shortages so it is hoped that this research could be continued in order to get a better result for the society in general.
\end{abstract}

Keywords: errors, syntax, English conversation

\section{Introduction}

The use of language feels normal because it is true that without being taught by anyone a baby will grow along with the growth of the language, which is usually called the mother tongue (Dardjowidjojo, 2008). Research on the acquisition of children's language has been done a lot, but most of these studies examine the acquisition of the first language (mother tongue) and second language (Indonesian) in a bilingual family environment. The research that has been conducted has mostly examined the acquisition of the first language and second language of children from the beginning of knowing the language or starting to speak, where the children studied ranged from 1 year to 5 years for first language acquisition and 8 years old for second language acquisition

As a difference from studies that have been done, the researcher will raise the acquisition of children's language in learning foreign languages, especially English. This will be appointed as a scientific study because there is still rarely research on the acquisition of children's language in learning foreign languages. This research is important to be done to prove that it is not only the environment that has an important role in the process of language 
acquisition because every human being born has been equipped with a tool to obtain language or known as language acquisition device/LAD (Chomsky, 1972).

There are several studies that become a reference before the researcher conduct this research, Beratha (1988) emphasizes his research on the problems faced by students about learning English. The approach used for the problem is in accordance with students' view of English as a foreign language situation, where these students are students who study English as a subject at school or at university while studying all subjects (subjects) through a media from the national language and do not use English outside of school or university.

Sudipa, et al (2011) examine the interference phenomenon as an important and urgent study. This is caused because the success of a speaker to communicate both verbally and in writing is determined by avoiding the use of other aspects of language when using certain languages. In this case the avoidance of students using aspects of Indonesian when using English. Studies to obtain a systematic picture of interference among foreign language enthusiasts need to be continued and carried out. This is in line with everyone's efforts to improve their ability and foreign language skills, especially in English. The quality of modern human resources is characterized by the ability and skills of a person to communicate both oral and written internationally satisfactorily.

This study aims to discuss phenomena that occur in the community, especially in schools where students are studying foreign languages, especially English, where there are students who have good language skills, this is related to the use of written language. This can be proven by some students who get good grades in answering questions given by the teacher. However, the use of spoken language can be said to be lacking, seen by no single student who has the courage to communicate in English. Researcher found this phenomenon occurred in a school located in Singaraja namely SD No. 1 Kendran when making initial observations before the researcher conducted research.

The students who were the subjects in this study were students who were still in class V of 11-year-old elementary school and had a good interest in the school in terms of learning English. The age of 11 years was chosen because at that age the child already had an adequate foreign language proficiency (English), which by the time the child was 10 (grade IV) already had English lessons in class even though it was only an initial introduction as a bridge to learning English in greater depth at a higher level of education.

The researcher needs a 5-grade elementary school syllabus to be used as a reference before giving topics to students in making short dialogues. The syllabus has an important role to limit the topics given by the 
researcher to students in the process of data collection so that the topics given by the researcher do not overlap with the material in the syllabus of the 5 th grade of elementary school students. students do not work too broad and in accordance with the syllabus, they use in the teaching and learning process at the school. The syllabus used by students has basic competencies that are, responding to instructions is very simple by acting in an acceptable manner in the classroom and school context, and responding to instructions is very simple verbally.

Furthermore, the teaching material in the syllabus is, (1) Pets and Colors, and accompanied by several examples of communicative expressions, such as This is a dog, It is white, What is that? and Do you like it ?, (2) Days in a week, months in a year, and Weather, accompanied by several examples of communicative expressions, such as: What day is it?, It is Friday, It is cold, it was hot yesterday, Is it Sunday today?, It was Wednesday yesterday, and It will be Friday tomorrow, and (3) Describing Things and People, accompanied by several examples of communicative expressions, such as The classroom is wide, She is fat, How is Ratna?, and She is pretty. Researchers only quote two of the many basic competencies that are in the school syllabus. In this study, there are several aspects of linguistics that are examined in more depth and thoroughly. The aspects studied are aspects of lexical use, as well as mastery of English syntax experienced by students.
The formulation of the problem found is how is the syntax mastery in English in grade 5th elementary school students. In this study, the researcher used the book Error Analysis on Second Language Acquisition by Jack C. Richards (1974) to examine the errors that occur during students doing English acquisition.

\section{Method}

The research methods applied in this study consisted of the research approach, types and sources of data, methods, and techniques of data collection, methods, and techniques of data analysis, as well as methods and techniques for presenting the results of data analysis. This study uses a qualitative approach that is sourced from data on observations made by researchers of Elementary School 5th Grade Students. The data was collected using the method of listening with the techniques of engaging in engaging and competent methods of interviewing. Intralingua equivalent method is used to analyze data that has been classified. Furthermore, the results of the analysis are presented using formal and informal methods.

\section{Finding and Discussion Errors in syntax}

Students' errors in relation to syntactic included errors in forming of clauses, errors in arranging of phrases, errors in using articles, errors in using prepositions, errors in using copula be, and errors in using to (infinitive). The syntactic errors conducted by 
students would be explained in details as follows:

\section{A. Clauses}

\section{a. Independent Clause}

The error conducted by students in relation with independent clause:

(16) I_reading comic

(dialogue no 1)

It supposed to be:

I am reading a comic.

The independent clause is categorized as an error clause because of the omitting of copula be (in this case, am) and without any articles. Therefore, without copula be and any articles, so this independent clause is categorized as unacceptable syntactically.

(17) I _ watching television with my father (dialogue no 1)

It supposed to be:

I am watching television with my father

The independent clause is categorized as an error clause because of the omitting of copula be (in this case, am) and without any articles. Therefore, without copula be and any articles, so this independent clause is categorized as unacceptable syntactically.

\section{b. Dependent Clause}

The error conducted by students in relation with dependent clause:

(18)I thirsty, I want_drink__ juice

(dialogue no 10)

It supposed to be:
I am thirsty, I want to drink a glass of juice

The dependent clause is categorized as an error clause because of the omitting of copula be (in this case, am), any preposition and without any articles. Therefore, without the presence of copula be (in this case, am), any preposition and any articles, so this dependent clause is categorized as unacceptable syntactically.

\section{B. Phrases}

\section{a. Noun Phrase}

The error conducted by students in relation with noun phrase:

(19) Saw small

(dialogue No 31)

It supposed to be:

Small saw

This noun phrase is a phrase that is less syntactically acceptable because it follows the rules of the ordering of words in Indonesian namely modifier-head. Meanwhile, the rules should be followed is English rules in ordering of words namely head-modifier. Here, the word saw is the head, then the word small function as modifier of saw. So, the word saw is modified by small.

\section{b. Adverbial Phrase}

The error conducted by students in relation with adverbial phrase:

(20) I_ close the window slow

(dialogue no 33)

It supposed to be:

I will close the window slowly 
The sentence "I_close the window slow", the ordering words of this sentence is classified as unacceptable syntactically in English. It is because of omitting of modal auxiliary that refer to future tense (will) and adverb. The adverb (slowly) explains about noun, the window.

\section{Articles}

The error conducted by students in relation with article:

(21) When_you go to bookstore?(dialogue no 4)

It supposed to be:

"When do you go to the bookstore?"

To get a proper words order of this sentence (question), the suitable article is "the". It is because the word bookstore refers to a certain place that is already known by both the speaker and the hearer. Furthermore, do not forget to put auxiliary verb (do) after when to make the proper question syntactically.

(22) I want_drink___ juice

(dialogue no 10)

It supposed to be:

I want to drink a glass of juice

To get a proper words order of this sentence, the sentence need a presence of article. The suitable article is "a glass of". Moreover, the sentence also need to (infinitive) before the word drink.

(23) What transportation device in sea? (dialogue no 18)

It supposed to be:

What is transportation device in the sea?
To get a proper words order of this sentence (question), the suitable article is "the". It is because the word sea refers to a certain place that is already known by both the speaker and the hearer. Furthermore, do not forget to put copula be (is) after what to make the proper question syntactically.

(24) You should take_medicine.

(dialogue 24)

It supposed to be:

You should take a medicine.

To get a proper words order of this sentence, the suitable article is " $a$ ". It is because the word medicine refers to a singular item. After putting an article (in this case, a), the sentence is categorized as acceptable syntactically.

(25) Yes, I have_dog

(dialogue 15)

It supposed to be:

Yes, I have a dog

To get a proper words order of this sentence, the suitable article is "a". It is because the word dog refers to a singular item. After putting an article (in this case, a), the sentence is categorized as acceptable syntactically.

(26) clean_table

(dialogue 16)

It supposed to be:

To clean the table / cleaning the table

To get a proper words order of this sentence, the suitable article is "the". It is because the word table 
refer to a certain thing that is already known by both the speaker and the hearer. Furthermore, do not forget to change the verb (clean) in to cleaning or to clean to make the proper question syntactically. It is because the verb clean function as subject so the form of subject must be gerund (cleaning) or to infinitive (to clean).

\section{Preposition}

The error conducted by students in relation with preposition:

(27) You should listen _ your parent's advice (dialogue no 30)

It supposed to be:

"You should listen to your parent's advice"

In English syntax (grammar), the presence of prepotion in a sentence in very important. If a sentence need a preposition, you must put a preposition to make the sentence is acceptable syntactically in English.

\section{E. Copula be}

The error conducted by students in relation with copula be:

(28) I_ going to bookstore now

(dialogue no 4)

It supposed to be:

I am going to bookstore now

In the rules of English, the role of copula be is very important if there is no copula in sentences that should require a sentence in English, so the sentence can be classified as not syntactically acceptable.

(29) It_not difficult for me

(dialogue no 7)

It supposed to be:
It is not difficult for me

In the rules of English, the role of copula be is very important if there is no copula in sentences that should require a sentence in English, so the sentence can be classified as not syntactically acceptable.

(30) My_body very thin

(dialogue no 8)

It supposed to be:

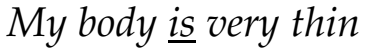

In the rules of English, the role of copula be is very important if there is no copula in sentences that should require a sentence in English, so the sentence can be classified as not syntactically acceptable

(31) I_watching television with myfather (dialogue no 21)

It supposed to be:

I am watching television with my father

In the rules of English, the role of copula be is very important if there is no copula in sentences that should require a sentence in English, so the sentence can be classified as not syntactically acceptable.

(32) She_very happy

(dialogue 22)

It supposed to be:

She is very happy

In the rules of English, the role of copula be is very important if there is no copula in sentences that should require a sentence in English, so the 
sentence can be classified as not syntactically acceptable.

(33) He_repairing roof

(dialogue 34)

It supposed to be:

He is repairing roof

In the rules of English, the role of copula be is very important if there is no copula in sentences that should require a sentence in English, so the sentence can be classified as not syntactically acceptable.

\section{F. To (infinitive)}

The error conducted by students in relation with to (infinitive):

(34) I want_buy book

(dialogue no 14)

It supposed to be:

"I want to buy a book"

In English, the infinitive form functions as an object or a complement of a verb, adjective, or noun. Specifically, in accordance with the above sentence, this infinitive functions as the object of a verb.

Academia realized that learning a foreign language provides more challenges for young age learners. In learning a foreign language, English for instance, the defiance can be found in studying form basic to advance level. According to the findings above, the errors in using English found in the Elementary School 5th Grade Students related to syntax which included: errors in the scope of clause (independent and dependent clauses) and phrase (noun phrase and adverbial phrase), the omission of the article (the, a, and a glass of) and preposition (to), the omission of copula be and error in using to (infinitive). In addition, the most errors related to syntax are the omission of article and copula be. The error of using basic English structure such as the omission of the article was homework for teachers to give students drilling in terms of improving elementary students' skills in basic English structure.

These mistakes might bring a wider impact on using a foreign language if teachers do not guide the students to learn and fix the error base on the correct structure. Learning a basic foreign language at a younger age will be an advantage for learners. Students know how to practice the language earlier which helps them to be more fluent in using English as a foreign language.

\section{Conclusion}

From the situation found by the writer, methodology in decreasing students' mistakes in learning English structure is needed during the learning instructional in the classroom. Transferring a language structure to the children needs extra efforts for the teacher in gaining the learning goal. It is suggested to the mentors that providing a strategy to rise students understanding of basic structure before explaining the medium and advance level English grammar.

Providing games, technology, and class interaction in learning grammar, for instance, can urge students to be 
more active in the classroom. Using games for students may assist children to get more exciting as learners feel fun, challenge, and find the visual which can attract students to learn the topic. In terms of technology, this can be beneficial for teachers in delivering structure materials, using computers, laptops, I Pads or smartphone through the learning process encourage children's curiosity. This combination of learning methodologies is an opportunity for teachers or researchers to explore the strategy in enhancing students' language structures skills.

\section{Bibliography}

Beratha, N. L. S. 1988. An Investigasion of Variables in Translation into English by Students at Udayana University. Melbourne: Monash University.

Chomsky, N. 1972. Language and Mind. New York: Harcourt Brace Jovanovich.

Cook. V. 1996. Second Language Learning and Language Teaching, $2^{\text {nd }} E d$. New York: Arnold, Hodder Headling Group.

Dardjowidjojo, S. 2008. Psikolinguistik: Pengantar Pemahaman Bahasa Manusia. Jakarta: Yayasan Obor Indonesia.

Dharmowijono, W. W. dan Suparwa I N. 2009. Psikolinguistik: Teori Kemampuan Berbahasa dan Pemerolehan Bahasa Anak. Denpasar: Udayana University Press.
Mahsun. 2005. Metode Penelitian Bahasa: Tahapan Strategi, Metode dan Tekniknya. Jakarta: PT. RajaGrafindo Persada.

Richards, J. C. 1974. Error Analysis of Second Language Acquisition. London: Longman.

Saville-Troike, M. 2006. Introducing Second Language Acquisition. Cambridge: Cambridge Univesity Press.

Swan, M. 1995. Practical English Usage, $2^{\text {nd }} E d$. Oxford: Oxford University Press

Sudaryanto. 1993. Metode dan Aneka Teknik Analisis Bahasa. Yogyakarta: Duta Wacana University Press.

Sudipa, I N., Rajeg, I M., Laksminy, L. P. 2011. Interferensi: Pengaruh Bahasa Indonesia dalam Bahasa Inggris. Denpasar: Udayana University Press. 